\title{
FAKTOR DETERMINAN YANG MEMPENGARUHI KINERJA DOSEN BERBASIS MUTU PERGURUAN TINGGI
}

\author{
Farida \\ Fakultas Tarbiyah dan Keguruan, Universitas Islam Negeri Raden Intan Lampung \\ farida@radenintan.ac.id
}

\begin{abstract}
Abstrak
Artikel ini memberikan kontribusi untuk mengetahui ada tidaknya pengaruh: (1) kepemimpinan terhadap kinerja dosen berbasis mutu Perguruan Tinggi, (2) motivasi dosen terhadap kinerja dosen berbasis mutu Perguruan Tinggi, (3) iklim kampus terhadap kinerja dosen berbasis mutu Perguruan Tinggi, (4) kepemimpinan, motivasi dosen, dan iklim kampus terhadap kinerja dosen berbasis mutu Perguruan Tinggi. Metode yang akan digunakan dalam artikel ini adalah metode survey. Sesuai dengan variabel-variabel yang ada di dalam artikel ini maka penentuan responden yang menilai adalah sebagai berikut: kepimpinan dengan responden pejabat di lingkungan UIN Raden Intan Lampung. Motivasi prestasi dengan responden dosen. Iklim kampus, dengan responden dosen. Kinerja dosen berbasis mutu perguruan tinggi dengan responden dosen. 3Untuk teknik analisis yang digunakan adalah path analisis, dengan melakukan beberapa uji antara lain meliputi uji persyaratan statistic sebagai persyaratan, uji korelasi dan uji path atau path analysis. Hasil analisis dan pembahasan yang didapat adalah sebagai berikut; (1) Kepemimpinan berpengaruh langsung terhadap kinerja dosen berbasis mutu Perguruan Tinggi dan tidak mempunyai pengaruh tidak langsung, (2) Motivasi berpengaruh langsung maupun tidak langsung terhadap kinerja dosen (3) Iklim Kampus berpengaruh langsung terhadap kinerja dosen. (4) Kepemimpinan, motivasi dosen, dan iklim kampus secara bersama-sama berpengaruh langsung terhadap kinerja dosen berbasis mutu Perguruan Tinggi.
\end{abstract}

Kata Kunci: Iklim Kampus, Kepemimpinan, Kinerja Dosen, Motivasi Dosen 


\section{PENDAHULUAN}

Kehidupan abad globalisasi yang sering juga dikatakan dunia tanpa batas, ditandai dengan abad informasi, dimana ilmu pengetahuan berkembang sangat cepat. Brojonegoro mengatakan bahwa, "paradigm baru pendidikan tinggi pada dasarnya bertumpu pada tiga pilar utama, yakni kemandirian dalam pengelolaan atau otonomi, akuntabilitas (accountability), dan jaminan mutu (quality assurance)".(Jalal \& Dedi, 2001)

Berdasarkan hal tersebut, mutu pendidikan haruslah sesuai dengan atau melebihi kebutuhan dan tuntutan pendidikan itu sendiri. Perlu dipahami bahwa untuk memenuhi kepuasan pelanggan pendidikan tidaklah mudah terpenuhi, karena beberapa faktor seperti: (a) peserta didik mempunyai kebutuhan yang berbeda-beda, (b) kebutuhan peserta didik juga dapat berubah-ubah seiring dengan perjalanan kedewasaan, pengalaman dan keyakinan persepsi mereka, (c) kemampuan, pengalaman, dan sikap para pendidik juga berbeda-beda, dan (d) lingkungan keluarga dan motivasi belajar peserta didik juga tidak sama. Upaya mengatasi berbagai permasalahan tersebut, diperlukan manajemen pendidikan yang lebih peduli terhadap kualitas layanan jasa kependidikan.

Dewasa ini dirasakan bahwa, kebutuhan akan lulusan perguruan tinggi yang mempunyai paradigma global disertai jati diri bangsa Indonesia serta kemampuan menjalani jaringan kerja yang dapat merebut persaingan global sudah sangat dibutuhkan. Oleh karena itu diperlukan pengelolaan perguruan tinggi yang berkualitas, motivasi berprestasi yang tinggi serta kompetensi dosen yang memadai didukung oleh budaya organisasi yang kondisif, dan yang terpenting adalah diperlukannya kinerja dosen yang berbasis mutu. Pengelolaan secara professional tidak hanya diperlukan terhadap organisasi perguruan tinggi saja, tetapi juga diperlukan pengelolaan terhadap pencapaian mutu, sehingga dalam pencapaian mutu tersebut menjadi efektif.

Salah satu filosofi, teori dan peraktek manajemen yang peduli terhadap peningkatan kualitas adalah Total Quality Management (TQM). Meskipun berasal dari dunia industri, prinsip-prinsip TQM telah banyak diterapkan pada lembaga pendidikan. Dijelaskan oleh Sallis bahwa, "TQM is a philosophy of continuous improvement, which can provide any educational institusion with a set of partical tools for meeting and exceeding present and future customers needs, wants, and expectations" (Sallis, 1993). Kemudian Tampubolon (2001) menjelaskan bahwa masalah mutu perguruan tinggi adalah kesesuaian paduan sifat sifat produknya dengan kebutuhan para pelanggannya. (Tampubolon, 2001)

Definisi mutu perguruan tinggi berdasarkan konsep Crosby, adalah paduan sifat-sifat produk yang menunjukan kemampuannya dalam memenuhi 
kebutuhan pelangggan langsung atau tak langsung, baik kebutuhan yang dinyatakan maupun yang tersirat, masa kini dan masa depan. Berdasarkan definisi tersebut maka, mutu perguruan tinggi harus dilihat dari seluruh produknya, bukan hanya dari tingkat kemampuan lulusannya, tetapi setiap jasa yang dihasilkan harus dievaluasi untuk mengetahui apakah sesuai dengan kebutuhan pelanggan. Oleh karena itu perguruan tinggi bermutu dipahami sebagai lembagai pendidikan tinggi yang terkelola sedemikian rupa sehinggga mampu menghasilkan jasa kependidikan tinggi yang sesuai dengan kebutuhan para pelanggan.

Universitas Islam Negeri Lampung merupakan salah satu perguruan tinggi negeri yang ada di wilayah Sumatra dan memiliki posisi yang strategis, walaupun berada di Pulau Sumatra tetapi tidak jauh dari pusat pemerintahan Jakarta. Sehingga mahasiswa yang belajar di Universitas Islam Negeri Lampung tidak saja berasal dari daerah Lampung dan daerah Sumatra lainnya tetapi jugan dari berbagai kota. Oleh karena itu Universitas Islam Negeri Lampung perlu memperhatikan peningkatan kualitas pendidikan supaya dapat memberikan pelayanan yang terbaik dan stakeholder.

Berdasarkan hasil monitoring yang dilakukan oleh tim evaluasi penjaminan mutu tahun 2006 menunjukan bahwa, kinerja Universitas Islam Negeri Lampung baik kinerja dosen maupun lembaga jurusan belum menunjukan hasil yang memuaskan. Hasil yang dicapai setiap jurusan masih dibawah nilai rata-rata. Hal ini diduga karena faktor kepemimpinan, motivasi dosen, dan iklim kampus belum mencapai seperti apa yang diharapkan, sehingga berpengaruh terhadap kinerja dosen yang ditampilkan.

Penulis berasumsi terdapat faktor-faktor yang mempengaruhi kondisi tersebut, diantaranya adalah faktor kepemimpinan ketua jurusan, motivasi dosen, kompetensi dosen, budaya organisasi, dan tentu saja dosen yang bersangkutan, seperti yang dikemukakan oleh Miler dalam Kusumastuti yang intinya mengemukakan bahwa, dosen adalah komponen vital, penggerak utama bagi faktor kesuksesan dari sistem pendidikan dan pengajaran yang akhirnya akan mempengaruhi produktivitas perguruan tinggi. (Kusumstuti, 2002). Dosen sebagai salah satu penjamin mutu dalam proses pendidikan merupakan tenaga kependidikan yang profesional dituntut mempunyai kompetensi sehingga, dapat mewujudkan standar kerja yang bermutu selanjutnya diharapkan bermuara pada peningkatan mutu kinerja dosen maupun organisasi perguruan tinggi dan berdampak pada mutu pendidikan atau mutu lulusan perguruan tinggi.

Berdasarkan hal tersebut seorang dosen sebagai tenaga kependidikan di lingkungan perguruan tinggi dituntut memiliki profesionalisme. Seorang yang memilih profesi sebagai dosen harus dilandasi oleh panggilan jiwa atau dengan kata lain sesuai dengan keinginan hatinya. Faktor selanjutnya yang tidak kalah penting yang berkaitan dengan profesionalismme adalah 
keinginannya belajar untuk mengembangkan diri. Setiap orang termasuk juga dosen di lingkungan perguruan tinggi harus setiap saat mengembangkan kemampuannya agar tidak tertinggal dari perkembangan zaman. Profesionalisme itu penting mengingat dosen setiap saat harus mengembangkan kemampuannya dalam rangka mengikuti perkembangan dan perubahan zaman yang berjalan secara dinamis" oleh karena itu, hendaknya dosen senantiasa mampu menjadi panutan bagi mahasiswanya dan menyadari betapa pentingnya belajar secara terus menerus dalam rangka mengembangkan diri dalam profesi dan prestasi untuk mencapai tujuan yang telah ditetapkan dengan mengembangkan diri tersebut, diharapkan dosen yang perfesional yang bermutu dapat terwujud.

Selain dari beberapa faktor seperti yang telah disebutkan di atas, yang diperkirakan ikut mempengaruhi kinerja dosen adalah faktor kepemimpian. Kepemimpinan merupakan salah satu faktor penentu peningkatan mutu pendidikan perguruan tinggi bermutu, seperti dikatakan oleh james A.F Stoner (Nawawi, 2003), bahwa faktor pemimpinan sebagai salah satu komponen penting dalam peningkatan mutu pendidikan.

Konsep kinerja merujuk pada tingkat pencapaian persyaratan pekerjaan. Kinerja adalah prestasi yang dapat dicapai oleh seseorang atau organisasi berdasarkan kriteria dan alat ukur tertentu. Berdasakan pendapatpendapat tersebut maka dapat dikatakan bahwa, kinerja adalah prestasi atau pencapaian hasil kerja yang dicapai berdasarkan ukuran penelitian yang telah ditetapkan.

Berdasarkan uraian latar belakang masalah, pokok masalah yang diteliti dalam penelitian ini adalah bagaimanakah pencapaian kinerja dosen yang berbasis mutu dengan melihat pada pengaruh kepemimpinan, motivasi dosen, iklim kampus, dan kinerja dosen. Fokus penelitian ini akan ditekankan dan diarahkan pada pengungkapan gambaran tentang keadaan dari faktorfaktor kepemimpinan, motivasi dosen, iklim kampus, bagaimana pengaruhnya terhadap kinerja dosen dalam rangka pencapaian mutu di Universitas Islam Negeri Lampung.

Artikel ini memberikan kontribusi untuk mengetahui ada tidaknya pengaruh: (1) kepemimpinan terhadap kinerja dosen berbasis mutu Perguruan Tinggi, (2) motivasi dosen terhadap kinerja dosen berbasis mutu Perguruan Tinggi, (3) iklim kampus terhadap kinerja dosen berbasis mutu Perguruan Tinggi, (4) kepemimpina, motivasi dosen, dan iklim kampus terhadap kinerja dosen berbasis mutu Perguruan Tinggi. Adapun beberapa hasil penelitian terdahulu diperoleh secara keseluruhan menunjukkan kompetensi, motivasi dan kepemimpinan berpengaruh kuat terhadap efektivitas pelaksanaan Tridharma Perguruan Tinggi (Kerja \& Apriani, 2009), (Setiawati, 2013)

Kajian pustaka pada artikel ini mengambil dua penelitian sebelumnya yang masing-masing penulisan memiliki kesamaan dan perbedaan, sebagai berikut: 


\section{METODE PENELITIAN}

Metode yang akan digunakan dalam aerikel ini adalah metode survei. Penelitian survei merupakan upaya pengumpulan informasi dari sebagian populasi yang dianggap dapat mewakili populasi tertentu. Populasi target pada penelitian ini akan dilakukan pada seluruh warga kampus, baik itu dosen, pegawai administrasi serta karyawan. Sampel; Metode pengambilan jumlah sampel yang akan digunakan pada penelitian ini adalah berdasarkan S. Nasution yang menyatakan jumlah sampel minimal $10 \%$ dari populasi yang ada. (Nasution, 2002). Sesuai dengan variabel-variabel yang ada di dalam penelitian ini maka penentuan responden yang menilai adalah sebagai berikut: kepimpinan dengan responden pejabat di lingkungan UIN Raden Intan Lampung. Motivasi prestasi dengan responden dosen. Iklim kampus, dengan responden dosen. Kinerja dosen berbasis mutu perguruan tinggi dengan responden dosen.

Untuk analisis penelitian sosial yang kaitannya dengan causal, maka teknik analisis yang digunakan adalah path analisis. Untuk mencapai analisis tersebut maka dilakukan beberapa uji antara lain meliputi uji persyaratan statistic sebagai persyaratan, uji korelasi dan uji path atau path analysis. Variabel di dalam penelitian ini meliputi kebijakan pimpinan $\left(\mathrm{X}_{1}\right)$, motivasi prestasi $\left(\mathrm{X}_{2}\right)$, iklim kampus $\left(\mathrm{X}_{3}\right)$ dan yang disebut dengan variabel respon atau mempengaruhi, terhadap kinerja dosen berbasis mutu perguruan tinggi $\left(\mathrm{X}_{4}\right)$ yang disebut dengan variabel predictor atau yang dipengaruhi. Gambaran beberapa analisis yang digunakan dalam penelitian ini adalah sebagai berikut: Uji coba (try out) instrumen, Uji kelayakan data, Analisis deskripsi data.

\section{PEMBAHASAN}

Hasil analisis data penelitian yang diolah dengan menggunakan statistik. Pada penelitian ini beberapa analisis yang digunakan untuk mengolah data lapangan berupa analisis deskripsi, dan analisa jalur. Analisis deskripsi digunakan untuk mengetahui keadaan masing-masing variable. Analisis yang dilakukan meliputi: nilai rata-rata, median, modus, varian, simpangan baku, serta visualisasi data berupa tabel dan grafik.

Analisis jalur (path analysis) yaitu analisis untuk mengetahui adanya pengaruh antara variabel mempengaruhi terhadap variabel yang dipengaruhi di dalam kausal. Untuk mencapai analisis jalur dilakukan beberapa analisis sebagai dasar perhitungan, yang meliputi: uji regresi, uji korelasi, dan uji pengaruh. Uji tersebut digunakan untuk menentukan adanya hubungan dan pengaruh antar variabel.

Sebelum uji analisis data, dilakukan dahulu uji prasyarat analisis yang meliputi uji normalitas dan uji homogenitas data. Uji normalitas data dengan 
tujuan mengetahui normal atau tidaknya distribusi data. Uji normalitas menggunakan rumus Lilliefors. Uji homogenitas dengan tujuan mengetahui data yang ada homogen atau tidak data antar variabel dalam kausal. Uji homogenitas data menggunakan rumus Barlet.

\section{Pengujian Prasyarat Analisis}

Analisis jalur atau path analysis merupakan analisis yang mencari pengaruh di dalam kausal antar variabel. Pada umumnya analisis statistik yang menggunakan uji hipotesis yang telah diprediksi sebelumnya berdasarkan teori yang ada. Untuk uji hipotesis yang membuktikan suatu kausal antar variabel maka terdapat beberapa uji prasyarat sebelum melakukan uji analisis. Untuk melakukan analisis jalur ini harus memenuhi persyaratan tertentu sehingga data layak dianalisis kausal antar variabel. Beberapa prasyarat yang harus dipenuhi meliputi: (1) data harus berdistribusi normal untuk setiap variabel dan (2 ) data harus homogen antar variabel emdogen terhadap variabel exogen.

\section{Uji Normalitas Data.}

Uji normalitas digunakan untuk mengetahui penyebaran data, apakah data tersebut berdistribusi normal atau tidak. Beberapa metode analisis yang dapat digunakan untuk melihat layak atau tidaknya data penelitian berdistribusi normal. Salah satunya dengan menggunakan metode Kolmogaorov-Smirnov berbantuan SPSS. Taraf signifikansi yang digunakan sebagai aturan untuk menolak atau menerima keputusan normal atau tidaknya suatu distribusi data pada penelitian sosial mempunyai tingkat signifikansi $\alpha$ $=0,05$. Data dikatakan berdistribusi normal jika sig. (2-tailed) $>\alpha=0,05$. Rangkuman hasil perhitungan dari keempat variabel yaitu, Kepemimpinan $\left(\mathrm{X}_{1}\right)$, Motivasi $\left(\mathrm{X}_{2}\right)$ dan iklim kampus $\left(\mathrm{X}_{3}\right)$ dan Kinerja Dosen $\left(\mathrm{X}_{4}\right)$ dapat dilihat pada tabel sebagai berikut:

Tabel 1. Rangkuman Hasil Uji Normalitas Data Galat Tafsiran

\begin{tabular}{ccccc}
\hline Variabel & $\mathbf{N}$ & Sig. & $\boldsymbol{\alpha = 0 , 0 5}$ & Kesimpulan \\
\hline $\mathbf{X}_{\mathbf{1}}$ & 25 & 0,895 & 0,05 & Normal \\
$\mathbf{X}_{\mathbf{2}}$ & 25 & 0,947 & 0,05 & Normal \\
$\mathbf{X}_{\mathbf{3}}$ & 25 & 0,951 & 0,05 & Normal \\
$\mathbf{X}_{\mathbf{4}}$ & 25 & 0,942 & 0,05 & Normal \\
\hline
\end{tabular}

Uji Homogenitas Varians

Uji homogenitas merupakan salah satu persyaratan yang harus dipenuhi dalam melakukan penelitian kuantitatif yang berbentuk kausal. Uji 
ini dilakukan untuk mengetahui apakah varians populasi data exogen bersifat homogen atau tidak terhadap data endogen. Analisis uji homogenitas varians dilakukan dengan menggunakan SPSS. Adapun dasar pengambilan keputusan dalam uji homogenitas adalah jika nilai signifikansi > 0,05, maka dikatakan bahwa varian dari dua atau lebih kelompok populasi data adalah sama maka dapat dinyatakan data endogen atas exogen bersifat homogen.

Tabel 2. Rangkuman Hasil Uji Homogenitas Varians data exogen atas data endogen.

\begin{tabular}{cccc}
\hline Antar varians & Sig. & $\boldsymbol{\alpha = 0 , 0 5}$ & Kesimpulan \\
\hline $\mathbf{X}_{\mathbf{2}} \mathbf{A T A S} \mathbf{X}_{\mathbf{1}}$ & 0,482 & 0,05 & Homogen \\
$\mathbf{X}_{\mathbf{3}}$ atas $\mathbf{X}_{\mathbf{1}}$ & 0,235 & 0,05 & Homogen \\
$\mathbf{X}_{\mathbf{4}}$ atas $\mathbf{X}_{\mathbf{1}}$ & 0,478 & 0,05 & Homogen \\
$\mathbf{X}_{\mathbf{3}}$ atas $\mathbf{X}_{\mathbf{2}}$ & 0,231 & 0,05 & Homogen \\
$\mathbf{X}_{\mathbf{4}}$ atas $\mathbf{X}_{\mathbf{2}}$ & 0,302 & 0,05 & Homogen \\
$\mathbf{X}_{\mathbf{4}}$ atas $\mathbf{X}_{\mathbf{3}}$ & 0,460 & 0,05 & Homogen \\
\hline
\end{tabular}

\section{Pengujian Model Jalur Struktural}

Nilai koefisien jalur didasarkan atas nilai korelasi pada jalur-jalur kausal. Koefisien korelasi jalur diperoleh nilai sebagai berikut:

$$
\begin{array}{lll}
\mathrm{R}_{12}=0,841 & \mathrm{r}_{23}= & 0,948 \\
\mathrm{R}_{13}=0,798 & \mathrm{r}_{24}= & 0,918 \\
\mathrm{R}_{14}=0,807 & \mathrm{r}_{34}= & 0,898
\end{array}
$$

Berdasarkan hasil koefisien korelasi tersebut dapat digunakan sebagai dasar untuk menghitung koefisien jalur. Hasil analisis uji pengaruh diperoleh nilai koefisien pengaruh sebagai berikut:

$$
\begin{array}{lllc}
\mathbf{P}_{21}= & 0,841 & \mathbf{\rho 4 1}= & 0 \\
\mathbf{P}_{31}= & 0,703 & \mathbf{\rho 4 2}= & 0 \\
\mathbf{P}_{32}= & 0,512 & \mathbf{\rho 4 3}= & 0,881
\end{array}
$$

Pengujian hipotesis penelitian pada analisis jalur dilakukan dengan cara "uji t", yaitu dengan membandingkan nilai $t$ hitung terhadap nilai $t$ tabel berdasarkan tingkat signifikansi koefisien jalur antar variabel yang ada. Besaran nilai tabel pada penelitian ini berdasarkan "Tabel Nilai Presentil distribusi " $t$ " dengan $n$ (banyak sampel) $=25$. Untuk pengaruh nyata menggunakan tingkat signifikansi 0,05 diperoleh nilai 1,67 dan untuk pengaruh sangat nyata menggunakan tingkat signifikani 0,01 diperoleh nilai 2,38 . Untuk mengetahui nilai signifikasi jika $t_{\text {hitung }}>t_{\text {tabel }}$ 


\section{Kepemimpinan Terhadap Motivasi}

Hipotesis yang diuji:

$\mathrm{H}_{0}: \mathrm{P}_{21}=0$ : Kepemimpinan tidak berpengaruh signifikan terhadap Motivasi.

$\mathrm{H}_{1}: \mathrm{P}_{21}>0$ : Kepemimpinan berpengaruh signifikan terhadap Motivasi.

Jika $\mathrm{t}$ hitung $\leq 0$ maka Kepemimpinan tidak berpengaruh signifikans terhadap Motivasi. Jika tidak terpenuhi hipotesis pertama $\left(\mathrm{H}_{0}\right)$ maka digunakan hipotesis alternatif yaitu: Jika $t_{\text {hitung }}>0$ maka Kepemimpinan berpengaruh signifikans terhadap Motivasi .

Dari hasil perhitungan diperoleh nilai koefisien jalur $\left(\mathrm{p}_{21}\right)=$ 0,841 dengan nilai $\mathrm{t}$ hitung $=7,321$. Nilai pada tabel $\mathrm{t}$ dengan tingkat signifikansi 0,05 dari jumlah responden $(n)=25$ diperoleh angka $t_{\text {tabel }}=$ 1,645 Hasil tersebut dapat menjawab $\left(\mathrm{H}_{0}\right)$ tidak terbukti, untuk itu digunakan hipotesis alternatif yaitu $\left(\mathrm{H}_{1}\right)$.

Berdasarkan hasil tersebut dapat disimpulkan bahwa Kepemimpinan berpengaruh signifikan terhadap Motivasi.

\section{Kepemimpinan Terhadap Iklim kampus}

Hipotesis yang diuji:

$\mathrm{H}_{0}: \mathrm{P}_{31}=0: \quad$ Kepemimpinan tidak berpengaruh signifikans terhadap Iklim kampus .

$\mathrm{H}_{1}: \mathrm{P}_{31}>0$ : Kepemimpinan berpengaruh signifikans terhadap Iklim kampus .

Jika $\mathrm{t}$ hitung $\leq 0$ maka Kepemimpinan tidak berpengaruh signifikans terhadap Iklim kampus. Jika tidak terpenuhi hipotesis pertama $\left(\mathrm{H}_{0}\right)$ maka digunakan hipotesis alternatif yaitu: Jika $t$ hitung $>0$ maka Kepemimpinan berpengaruh signifikan terhadap Iklim kampus

Dari hasil perhitungan diperoleh nilai koefisien jalur $\left(\mathrm{p}_{31}\right)=$ 0,703 dengan nilai $\mathrm{t}$ hitung $=7,112$. Nilai pada tabel $\mathrm{t}$ dengan tingkat signifikansi 0,05 dan jumlah responden $(n)=25$ diperoleh angka $t_{\text {tabel }}=$ 1,645 Karena nilai $t_{\text {hitung }}>t_{\text {tabel. }}$. Hasil tersebut dapat menjawab hipotesis pertama $\left(\mathrm{H}_{0}\right)$ tidak terbukti. Untuk itu, digunakan hipotesis alternatif yaitu $\left(\mathrm{H}_{1}\right)$.

Berdasarkan hasil tersebut dapat disimpulkan bahwa Kepemimpinan berpengaruh signifikan terhadap Iklim kampus.

\section{3) Motivasi Terhadap Iklim kampus}

Hipotesis yang diuji:

$\mathrm{H}_{0}: \mathrm{P}_{32}=0: \quad$ Motivasi tidak berpengaruh signifikans terhadap Iklim kampus 
$\mathrm{H}_{1}: \mathrm{P}_{32}>0$ : Motivasi berpengaruh signifikans terhadap Iklim kampus .

Jika $t_{\text {hitung }} \leq 0$ maka Motivasi tidak berpengaruh signifikans terhadap Iklim kampus . Jika tidak terpenuhi hipotesis pertama $\left(\mathrm{H}_{0}\right)$ maka digunakan hipotesis alternatif yaitu:

$\mathrm{H}_{1}: \mathrm{P}_{32}>0$ : Jika $\mathrm{t}$ hitung $>0$ maka Motivasi berpengaruh signifikans terhadap Iklim kampus .

Dari hasil perhitungan diperoleh nilai koefisien jalur $\left(\mathrm{p}_{32}\right)=$ 0,512 dengan nilai $t$ hitung $=13,952$. Nilai pada tabel $t$ dengan tingkat signifikansi 0,05 dan jumlah responden $(n)=80$ diperoleh angka $t_{\text {tabel }}=$ 1,645. Karena nilai thitung $>t_{\text {tabel. }}$. Hasil tersebut dapat menjawab hipotesis pertama $\left(\mathrm{H}_{0}\right)$ tidak terbukti, untuk itu digunakan hipotesis alternatif yaitu $\left(\mathrm{H}_{1}\right)$.

Berdasarkan hasil tersebut dapat disimpulkan bahwa Motivasi berpengaruh signifikans terhadap Iklim kampus.

\section{4) Iklim kampus Terhadap Kinerja Dosen}

Hipotesis yang diuji:

$\mathrm{H}_{0}: \mathrm{P}_{43}=0: \quad$ Iklim kampus tidak berpengaruh signifikan terhadap Kinerja Dosen.

$\mathrm{H}_{1}: \mathrm{P}_{43}>0$ : Iklim kampus berpengaruh signifikan terhadap Kinerja Dosen.

Jika $\mathrm{t}$ hitung $\leq 0$ maka Iklim kampus tidak berpengaruh signifikans terhadap Kinerja Dosen. Jika tidak terpenuhi hipotesis pertama $\left(\mathrm{H}_{0}\right)$ maka digunakan hipotesis alternatif yaitu: Jika $t$ hitung $>0$ maka Iklim kampus berpengaruh signifikans terhadap Kinerja Dosen.

Dari hasil perhitungan diperoleh nilai koefisien jalur $\left(\mathrm{p}_{43}\right)=$ 0,881 dengan nilai $t$ hitung $=11,003$. Nilai pada tabel $\mathrm{t}$ dengan tingkat signifikansi 0,05 dan jumlah responden $(n)=86$ diperoleh angka $t_{\text {tabel }}=$ 1,645. Karena nilai $t_{\text {hitung }}>t_{\text {tabel. }}$. Hasil tersebut dapat menjawab hipotesis pertama $\left(\mathrm{H}_{0}\right)$ tidak terbukti, untuk itu digunakan hipotesis alternatif yaitu $\left(\mathrm{H}_{1}\right)$.

Berdasarkan hasil tersebut dapat disimpulkan bahwa Iklim kampus berpengaruh signifikans terhadap Kinerja Dosen. Hasil uji hipotesis tersebut di atas maka dapat rangkuman nilai sebagai berikut: 
Tabel 4.14. Rangkuman Hasil uji Signifikansi Jalur Kausal Penelitian

\begin{tabular}{|c|c|c|c|c|c|c|}
\hline \multirow{2}{*}{\multicolumn{2}{|c|}{$\begin{array}{c}\text { Koefisien } \\
\text { Korelasi }\end{array}$}} & \multirow{2}{*}{\multicolumn{2}{|c|}{$\begin{array}{l}\text { Koefisien } \\
\text { Pengaruh }\end{array}$}} & \multirow{2}{*}{$\mathrm{t}_{\text {hitung }}$} & $\mathrm{t}$ table & \multirow{2}{*}{ Keterangan } \\
\hline & & & & & $a=0,05$ & \\
\hline $\mathbf{r}_{12}$ & 0,841 & $\mathbf{P}_{21}$ & 0,841 & 7,321 & 1,645 & Pengaruh signifikan \\
\hline $\mathbf{r}_{13}$ & 0,798 & $\mathbf{P}_{31}$ & 0,703 & 7,112 & 1,645 & Pengaruh signifikan \\
\hline $\mathbf{r}_{14}$ & 0,807 & p32 & - & - & - & \\
\hline $\mathbf{r}_{23}$ & 0,948 & م41 & 0,512 & 13,952 & 1,645 & Pengaruh signifikan \\
\hline $\mathbf{r} 24$ & 0,918 & $\rho 42$ & - & - & - & \\
\hline $\mathbf{r}_{34}$ & 0,898 & p43 & 0,881 & 11,003 & 1,645 & Pengaruh signifikan \\
\hline
\end{tabular}

Berdasarkan hasil analisis jalur dapat diketahui bahwa jalur-jalur dalam kausal mempunyai pengaruh yang signifikan. Dengan demikian hasil jalur tersebut merupakan jalur yang terbentuk dalam penelitian ini. Untuk itu tidak perlu dilakukan perhitungan nilai jalur ulang seperti halnya jika terdapat jalur ada yang drop. Berdasarkan hasil analisis, maka bentuk konstalasi kausal antar variabel, nilai koefisien pengaruh dan nilai korelasi pada masing-masing jalur dapat lihat gambar di bawah ini:

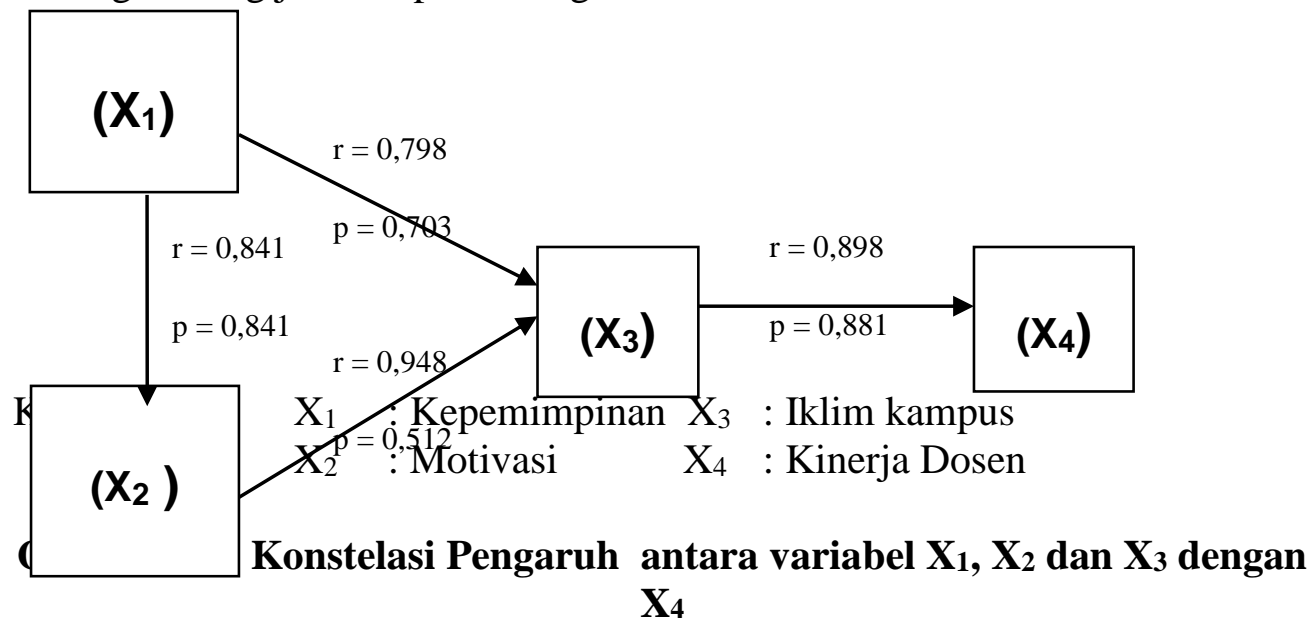




\section{c. Perhitungan Pengaruh Langsung dan Pengaruh Tidak Langsung.}

Hasil hipotesis di atas merupakan tingkat signifikansi yang dapat digunakan untuk mengetahui ada dan tidaknya pengaruh langsung dan tidak langsung antar variabel di dalam kausal, sebagai berikut:

1) Kepemimpinan terhadap Motivasi .

Berdasarkan hasil perhitungan nilai pengaruh dapat diketahui bahwa Kepemimpinan berpengaruh secara langsung terhadap Motivasi sebesar 0,598 atau 59,80\%. Karena pada jalur ini Kepemimpinan terhadap Motivasi tidak melalui variabel lain maka pengaruh tidak langsung $=$ nol.

2) Kepemimpinan terhadap Iklim kampus.

Berdasarkan hasil perhitungan nilai pengaruh dapat diketahui bahwa Kepemimpinan berpengaruh secara langsung terhadap Iklim kampus sebesar 0,821 atau 82,10\%. Karena pada jalur ini Kepemimpinan terhadap Iklim kampus melalui variabel lain Motivasi. Terdapat nilai pengaruh tidak langsung sebesar 0,493 atau 49,30\%. Dengan demikian nilai pengaruh secara keseluruhan 0,821 atau $82,10 \%$

3) Motivasi terhadap Iklim kampus .

Berdasarkan hasil perhitungan penentuan nilai pengaruh dapat diketahui bahwa Motivasi berpengaruh langsung terhadap Iklim kampus sebesar 0,924 atau 92,40\%. Karena pada jalur ini Motivasi terhadap Iklim kampus tidak melalui variabel lain maka pengaruh tidak langsung $=$ nol

4) Iklim kampus terhadap Kinerja Dosen.

Berdasarkan hasil perhitungan pada nilai pengaruh dapat diketahui bahwa terdapat pengaruh langsung sebesar 0,812 atau 81,20\%. Karena pada jalur ini Iklim kampus terhadap Kinerja Dosen tidak melalui variabel lain maka pengaruh tidak langsung $=$ nol.

Selain dari pengaruh langsung sesuai dengan model maka diperoleh juga nilai pengaruh tidak langsung adalah sebagai berikut: Kepemimpinan terhadap Kinerja Dosen berdasarkan hasil perhitungan pada nilai pengaruh dapat diketahui bahwa Kepemimpinan berpengaruh tidak langsung terhadap Kinerja Dosen secara keseluruhan sebesar 0,698 atau 69,80\%. Motivasi berpengaruh tidak langsung terhadap Kinerja Dosen melalui Iklim kampus dengan nilai sebesar 0,806 atau 80,60\%.

Berdasarkan hasil tersebut maka nilai pengaruh langsung dan tidak langsung pada penelitian disajikan sebagai berikut: 
Tabel 4. 15.

Nilai Koefisien Pengaruh Langsung dan Tidak Langsung Antar Variabel

Kausal.

\begin{tabular}{|c|c|c|c|}
\hline \multirow{2}{*}{ Jalur } & \multicolumn{3}{|c|}{ Nilai Koefisien Pengaruh } \\
\cline { 2 - 4 } & Langsung & Tak langsung & Total \\
\hline $\mathbf{P}_{\mathbf{2 1}}$ & 0,598 & 0,000 & 0,598 \\
\hline $\mathbf{P}_{\mathbf{3 1}}$ & 0,328 & 0,493 & 0,821 \\
\hline $\mathbf{P}_{\mathbf{3 2}}$ & 0,924 & 0,000 & 0,924 \\
\hline $\mathbf{P}_{\mathbf{4 3}}$ & 0,812 & 0,000 & 0,812 \\
\hline $\mathbf{P}_{\mathbf{4 1}}$ & 0,000 & 0,698 & 0,698 \\
\hline $\mathbf{P}_{\mathbf{4 2}}$ & 0,000 & 0,806 & 0,806 \\
\hline
\end{tabular}

Berdasarkan hasil analisis tersebut diketahui bahwa nilai pengaruh tertinggi adalah pengaruh Motivasi terhadap Iklim kampus, sedangkan nilai total terkecil pada pengaruh Kepemimpinan terhadap Motivasi.

\section{d. Rangkuman hasil analisis jalur.}

Berdasarkan perhitungan analisis jalur secara keseluruhan dapat dirangkum hasilnya sebagai berikut:

Tabel. 4. 16. Rangkuman Hasil Analisis Jalur Antar Variabel Kausal

\begin{tabular}{|c|c|c|c|c|c|c|c|c|}
\hline \multirow{2}{*}{ Kausal } & \multirow{2}{*}{$\begin{array}{l}\text { Koefisien } \\
\text { Korelasi }\end{array}$} & \multirow{2}{*}{$\begin{array}{l}\text { Kefisien } \\
\text { Pengaruh }\end{array}$} & \multirow{2}{*}{$t_{\text {hitung }}$} & \multicolumn{2}{|c|}{$t_{\text {tabel }}$} & \multicolumn{3}{|c|}{ Tingkat Pengaruh } \\
\hline & & & & 0,05 & 0,01 & Langsung & Tak langs & Total \\
\hline$X_{1} \rightarrow X_{2}$ & 0,841 & 0,841 & 7,321 & 1,66 & 2,330 & 0,598 & 0 & 0,598 \\
\hline$X_{1}->X_{3}$ & 0,798 & 0,681 & 7,112 & 1,66 & 2,330 & 0,328 & 0,493 & 0,821 \\
\hline$X_{1} \rightarrow X_{4}$ & 0,807 & 0,000 & 0,000 & 1,66 & 2,330 & 0 & 0,698 & 0,698 \\
\hline$X_{2}->X_{3}$ & 0,948 & 0,914 & 13,952 & 1,66 & 2,330 & 0,924 & 0 & 0,942 \\
\hline$X_{2}->X_{4}$ & 0,918 & 0,000 & 0,000 & 1,66 & 2,330 & 0 & 0,806 & 0,806 \\
\hline$X_{3}->X_{4}$ & 0,898 & 0,861 & 11,003 & 1,66 & 2,330 & 0,812 & 0 & 0,812 \\
\hline
\end{tabular}




\section{Pembahasan Hasil Penelitian.}

Berdasarkan analisis statistik yang telah diuraikan di depan dapat diketahui nilai-nilai hasil statistik pada masing-masing variabel dan tingkatan besarnya kausal pengaruh antara variabel endogen terhadap variabel exogen. Hasil tersebut dijadikan sebagai dasar dalam pembahasan penelitian, sebagai berikut:

\section{a. Kepemimpinan terhadap Motivasi}

Berdasarkan hasil analisis regresi dan korelasi diketahui bahwa Kepemimpinan dan Motivasi mempunyai hubungan membentuk persamaan regresi $\mathrm{X}_{2}=6,143+0,832 \mathrm{X}_{1}$. Uji keberartian regresi diperoleh nilai keberatian $F_{\text {hitung }}=28,102$ jauh di atas nilai $F_{\text {tabel }}=3,96$. dengan nilai koefisien korelasi sebesar 0,841. Hasil tersebut memberikan arti bahwa setiap peningkatan Kepemimpinan dapat meningkatkan Motivasi, dengan tingkat keterhandalan 84,1\%.

Hasil analisis jalur diketahui bahwa Kepemimpinan terhadap Motivasi mempunyai koefisien jalur sebesar 0,841 . Nilai signifikansi jalur pengaruh langsung diperoleh $t_{\text {hitung }}=7,321$, nilai ini lebih besar dari nilai $\mathrm{t}$ tabel $(0,01)=2,330$. Berdasarkan hasil tersebut dapat dinyatakan bahwa Kepemimpinan berpengaruh sangat signifikan terhadap Motivasi. Nilai koefisien pengaruh langsung sebesar 0,598.

Kepemimpinan tidak berpengaruh tidak langsung terhadap Motivasi . Karena model kausal yang terbentuk bahwa Kepemimpinan dalam mempengaruhi Motivasi tidak didapatkan variabel lain yang dilalui untuk menyatakan adanya pengaruh tidak langsung.

Hasil analisis penelitian yang menyatakan adanya pengaruh Kepemimpinan terhadap Motivasi selaras dengan teori pendukung. Sistem transparansi manajemen yang saat ini dilakukan di UIN Raden Intan Lampung secara langsung memaksa dosen dan karyawan untuk melakukan inovasi dan kreatifitas dalam pembelajaran sehingga tercipta arus informasi dari atasan ke bawahan atau sebaliknya. Kepemimpinan yang mendukung terbentuknya lingkungan yang menyenangkan, serta sistem kerja sama yang akan dilakukan menjadikan lingkungan yang kondusif. Hal ini dapat memacu atau meningkatkan Motivasi .

Demikian pula sistem manajemen yang diterapkan pada saat penelitian memacu Motivasi kerja. Kebebasan dalam mengemukakan gagasan baik di kelompok maupun pada saat interaksi juga menjadikan Motivasi yang kondusif antara dosen dengan dosen, dosen dengan pejabat dan dosen dengan karyawan.

Berdasarkan hasil yang diperoleh dari uji analisis dan didukung oleh adanya teori, maka dapat disimpulkan bahwa Kepemimpinan berpengaruh langsung terhadap Motivasi. Dengan demikian setiap indikator yang ada di Kepemimpinan dapat mempengaruhi Motivasi. 


\section{b. Kepemimpinan terhadap Iklim kampus}

Berdasarkan hasil analisis dapat diketahui bahwa Kepemimpinan maupun Iklim kampus berkriteria baik. Kedua variabel membentuk persamaan regresi $X_{3}=0,628+0,943 X_{1}$. Hubungan tersebut berbentuk linear dengan tingkat keberartian $F_{\text {hitung }}=46,809$ jauh lebih besar dari $\mathrm{F}_{\text {tabel }}=3,96>$ Hasil uji korelasi diperoleh nilai koefisien korelasi sebesar 0,798. Hasil tersebut dapat dinyatakan bahwa Kepemimpinan dengan Iklim kampus mempunyai hubungan seiring dan positif dengan tingkat keterhandalan $79,8 \%$.

Hasil analisis jalur diketahui bahwa Kepemimpinan mempunyai tingkat koefisien jalur pengaruh sebesar 0,681. Nilai signifikansi jalur pengaruh langsung diperoleh dengan thitung $=7,112$ lebih besar dari nilai $t$ tabel $(0,01)=2,330$. Berdasarkan hasil tersebut dapat dinyatakan bahwa Kepemimpinan berpengaruh sangat signifikan terhadap Iklim kampus. Besarnya pengaruh langsung terhadap Iklim kampus sebesar 32,8\%.

Kepemimpinan mempunyai berpengaruh tidak langsung terhadap Iklim kampus sebesar 49,3\%. Berdasarkan hasil yang diperoleh dari uji analisis dan didukung oleh adanya teori, maka dapat disimpulkan bahwa Kepemimpinan berpengaruh langsung maupun tidak langsung terhadap Iklim kampus. Dengan demikian setiap indikator yang ada di Kepemimpinan dapat mempengaruhi Iklim kampus.

\section{c. Motivasi terhadap Iklim kampus.}

Berdasarkan hasil analisis dapat diketahui bahwa Motivasi maupun Iklim kampus mempunyai kriteria baik. Kedua variabel dihubungkan dengan persamaan regresi $\mathrm{X}_{3}=3,018+0,914 \mathrm{X}_{2}$. Hubungan tersebut berbentuk linear terbukti dengan nilai keberartian $\mathrm{F}_{\text {hitung }}=234,312$ jauh lebih besar dari $\mathrm{F}_{\text {tabel }}=3,96$. Hasil uji korelasi diperoleh nilai koefisien korelasi sebesar 0,948. Hasil tersebut dapat dijelaskan bahwa Motivasi dengan Iklim kampus mempunyai hubungan seiring dan positip dengan tingkat keterhandalan 94,8\%.

Hasil dari analisis jalur diketahui bahwa Motivasi mempunyai koefisien jalur pengaruh sebesar 0,914. Nilai pengaruh tersebut cukup tinggi dilihat dari nilai signifikansi jalur pengaruh $\mathrm{t}$ hitung $=13,952>$ nilai $\mathrm{t}$ tabel $(0,01)=2,33$. Dengan demikian dapat dinyatakan Motivasi berpengaruh cukup tinggi, dan sangat sangat signifikan terhadap Iklim kampus. Besarnya nilai pengaruh langsung sebesar 92,40\%.

Adanya pengaruh antara Motivasi dengan Iklim kampus tidak terlepas adanya penerapan sistem manajemen yang baik. Sistem manajemen yang diterapkan pada saat penelitian memacu Iklim kampus. Kebebasan dalam mengemukakan gagasan baik di kelompok maupun 
pada saat interaksi juga menjadikan Iklim kampus yang kondusif antara dosen dengan dosen, dosen dengan pejabat dan dosen dengan karyawan.

Berdasarkan hasil yang diperoleh dari uji analisis dan didukung oleh adanya teori, maka dapat diketahui bahwa Motivasi berpengaruh langsung terhadap Iklim kampus. Dengan demikian setiap indikator yang ada di Motivasi dapat mempengaruhi Iklim kampus.

\section{d. Iklim kampus terhadap Kinerja Dosen.}

Berdasarkan hasil analisis dapat diketahui bahwa Iklim kampus maupun Kinerja Dosen termasuk berkriteria baik. Kedua variabel dihubungkan dengan persamaan regresi $\mathrm{X}_{4}=5,368+0,934 \mathrm{X}_{3}$. Hubungan tersebut berbentuk linear dengan nilai keberartian $\mathrm{F}_{\text {hitung }}=$ 114,021 jauh lebih besar dari $\mathrm{F}_{\text {tabel }}=3,96$. Hasil perhitungan korelasi diperoleh nilai koefisien korelasi sebesar 0,898. Hasil tersebut dapat dijelaskan bahwa terdapat hubungan seiring dan positif antara Iklim kampus dan Kinerja Dosen. Atau dengan perkataan lain bahwa semakin besar Iklim kampus maka semakin besar pula Kinerja Dosen. Keterhandalan hubungan tersebut sebesar $89,80 \%$.

Hasil dari analisis jalur diketahui bahwa Iklim kampus mempunyai dengan koefisien jalur pengaruh sebesar 0,861. Nilai signifikansi pengaruh tersebut $\mathrm{t}$ hitung $=11,003$ jauh lebih besar dari nilai $t_{\text {tabel }(0,01)}=2,330$. Berdasarkan nilai ini maka dapat dinyatakan bahwa Iklim kampus berpengaruh sangat besar dan besarnya nilai pengaruh Iklim kampus terhadap Kinerja Dosen sebesar 81,20\%.

Pengaruh Iklim kampus terhadap Kinerja Dosen dinyatakan pula dan dapat dinyatakan bahwa terdapat kemungkinan bahwa upaya Iklim kampus dapat meningkatkan Kinerja Dosen yang lebih tinggi.

\section{e. Kepemimpinan terhadap Kinerja Dosen.}

Berdasarkan hasil analisis dapat diketahui bahwa Kepemimpinan maupun Kinerja Dosen mempunyai kriteria baik. Kedua variabel dihubungkan dengan persamaan regresi $\mathrm{X}_{4}=5,549+0,872 \mathrm{X}_{1}$. Hubungan tersebut berbentuk linear dengan nilai keberartian regresi $F_{\text {hitung }}=31,021$ jauh lebih besar dari $F_{\text {tabel }}=3,96$ dan nilai koefisien korelasi sebesar 0,807. Hasil ini dapat dijelaskan bahwa Kepemimpinan mempunyai hubungan positip dan seiring dengan Kinerja Dosen dengan tingkat keterhandalan 80,70\%.

Di dalam kausal tidak ada nilai pengaruh langsung karena tidak ada jalur kausal yang menghubungkan. Namun demikian dari hasil analisis jalur diketahui bahwa Kepemimpinan mempunyai pengaruh tidak langsung terhadap Kinerja Dosen sebesar 69,80\%. 
Nilai ini membuktikan bahwa Kepemimpinan berperan secara tidak langsung terhadap Kinerja Dosen. Banyak teori Kinerja Dosen berkaitan dengan Kepemimpinan. Pengaruh Kepemimpinan terhadap Kinerja Dosen berkaitan dengan peranan dosen secara profesional dalam membentuk iklim baik yang efektif dan efisien.

Berdasarkan hasil yang diperoleh dari uji analisis dan didukung oleh adanya teori, maka dapat diketahui bahwa Kepemimpinan berpengaruh langsung maupun tidak langsung terhadap Kinerja Dosen. Dengan demikian setiap indikator yang ada di Kepemimpinan secara tidak langsung mempengaruhi Kinerja Dosen.

\section{f. Motivasi terhadap Kinerja Dosen}

Berdasarkan hasil analisis dapat diketahui bahwa Motivasi maupun Kinerja Dosen mempunyai berkriteria baik. Kedua variabel dihubungkan dengan persamaan regresi $\mathrm{X}_{4}=5,369+0,931 \mathrm{X}_{2}$. Hubungan tersebut berbentuk linear dengan nilai keberartian $F_{\text {hitung }}=$ 11,221 jauh lebih besar dari $\mathrm{F}_{\text {tabel }}=3,96$. Hasil uji korelasi diperoleh nilai koefisien korelasi sebesar 0,918. Hasil tersebut dapat dijelaskan bahwa terdapat hubungan seiring dan positif antara Motivasi dengan Kinerja Dosen dengan keterhandalan 91,80\%.

Kedua variabel tidak mempunyai jalur langsung, sehingga nilai koefisien jalur antara variabel tidak ada. Demikian pula nilai pengaruh langsungpun tidak ada. Namun berdasrkan hasil dari analisis jalur diketahui bahwa Motivasi mempunyai pengaruh tidak langsung terhadap Kinerja Dosen sebesar 80,60\%

Berdasarkan hasil yang diperoleh dari uji analisis dan didukung oleh adanya teori, maka dapat diketahui bahwa Motivasi berpengaruh tidak langsung terhadap Kinerja Dosen.

\section{PENUTUP}

Hasil analisis dan pembahasan yang didapat adalah sebagai berikut; (1) Kepemimpinan berpengaruh langsung terhadap kinerja dosen berbasis mutu Perguruan Tinggi dan tidak mempunyai pengaruh tidak langsung, (2) Motivasi berpengaruh langsung maupun tidak langsung terhadap kinerja dosen (3) Iklim Kampus berpengaruh langsung terhadap kinerja dosen. (4) Kepemimpinan, motivasi dosen, dan iklim kampus secara bersama-sama berpengaruh langsung terhadap kinerja dosen berbasis mutu Perguruan Tinggi.

Artikel ini mengupas secara detil bagaimana faktor kempemimpinan, motivasi dan iklim kampus mempengaruhi kinerja dosen berbasis mutu perguruan tinggi, sehingga bagi para peneliti dapat menjadi bahan acuan dan referensi dalam mengembangkan penelitian, khususnya pada variabel 
kepemimpinan, motivasi dan iklim kampus. Dakam pengembangan kinerja dosen berbasis mutu perguruan tinggi, artikel ini mengungkapkan besarnya pengaruh variabel variabel kepemimpinan, motivasi dan iklim kampus, hal ini dapat dijadikan sebagai penelitian fundamental bagi peneliti lain untuk mengembangkan atau meneliti kinerja dosen berbasis mutu perguruan tinggi dengan pengaruh faktor-faktor atau variabel lain. Bagi pemangku kebijakan, perlu upaya transformasi yang dapat mengadopsi penelitian ini dalam upaya pengembangan perguruan tinggi berbasis mutu. Dalam artikel ini juga dilihat seberapa besar pengaruh-pengaruh tiap variabel kepemimpinan, motivasi dan iklim kampus, sehingga dari hasil penelitian bisa dilihat variabel mana yang paling berpengaruh dan dapat dipertimbangkan untuk ditingkatkan bagi pemangku kebijakan dalam upaya peningkatan mutu perguruan tinggi.

\section{DAFTAR PUSTAKA}

\section{Jalal, F., \& Dedi, S. (2001). Reformasi Pendidikan dalam Konteks Otonomi}

Daerah. Yogyakarta: Depdiknas, BAPPENASS, Adicita Karyanusa.

Kerja, E., \& Apriani, F. (2009). Pengaruh Kompetensi, Motivasi, dan

Kepemimpinan terhadap Efektivitas Kerja. Bisnis \& Birokrasi, Jurnal

Ilmu Administrasi Dan Organisasi, 16(1), 13-17.

Kusumstuti, D. (2002). Manajemen Sistem Pembangunan Sumberdaya Dosen

Sebagai Penjamin Mutu di Perguruan Tinggi. Studi Tentang Pengaruh

Kompetensi Individu Terhadap Kinerja Dosen yang Berorientasi Pada

Mutu dengan Moderator Iklim Organisasi dan Dukungan Sumberdaya di Institut Te. Bandung: ITB.

Nasution, S. (2002). Metode Research. Jakarta: Bumi Aksara.

Nawawi, H. (2003). Kepemimpinan Mengefektifkan Organisasi. Yogyakarta:

Gadjah Mada University Press.

Sallis, E. (1993). Total Quality in Education. Philadelpihia: Kogan Page

Limited.

Setiawati, T. (2013). Pengaruh Kompetensi Kerja Terhadap Kinerja Dosen

(Studi Kasus Di FPTK UPI). Media Pendidikan, Gizi Dan Kuliner, 1(1), $1-5$.

Tampubolon, D. P. (2001). Perguruan Tinggi Bermutu, Paradigma Baru Manajemen Pendidikan Tinggi Menghadapi Tantangan Abad ke 21. Jakarta: PT.Gramedia Pustaka Utama. 